\title{
18. MESOZOIC MEGAFOSSILS FROM DSDP HOLE 327A AND SITE 330 ON THE EASTERN FALKLAND PLATEAU
}

\author{
David L. Jones and George Plafker, U.S. Geological Survey, Menlo Park, California
}

\begin{abstract}
Mesozoic megafossils obtained from DSDP Hole 327A and Site 330 on the Falkland Plateau consist of: bivalves, including Aucellina sp. juv., Inoceramus sp., Malayomaorica cf. $M$. malayomaorica (Krumbeck), Plicatula sp., and a new genus and species named Jeletzkiella falklandensis; belemnites, including representatives of Hibolithes and Belemnopsis; and fragments of ammonites and snails.

All the identified fossils have Austral, or Indopacific, affinities and are quite different from coeval Upper Jurassic and Lower Cretaceous faunas of southeastern and eastern Africa and Madagascar, which are of Tethyan affinities. Because of these faunal differences, the postulated predrift position of the eastern part of the Falkland Plateau lying close to the southeastern coast of Africa is questioned.
\end{abstract}

\section{INTRODUCTION}

Abundant and varied megafossils were collected from Upper Jurassic and Lower Cretaceous rocks cored at Hole $327 \mathrm{~A}$ and Site 330, which were drilled close together on the eastern Falkland Plateau. The distribution of megafossils in these holes is shown graphically in Figure 1, and the faunas collected are listed in Tables 1 and 2. Fossils consist predominantly of bivalve shells with subordinate belemnites, a fragmentary ammonite, and pieces of sponge. This paper outlines the distribution of the megafossils collected and briefly discusses the age, correlations, and paleoenvironmental significance of those that are specifically identifiable. In addition, a new bivalve genus and species are named and described.

Fossils described and figured in this paper are retained in collections of the U.S. Geological Survey, Menlo Park, California, and have been allotted U.S. Geological Survey Mesozoic locality numbers as indicated.

\section{BIOSTRATIGRAPHIC SUMMARY}

\section{Hole 327A}

Molluscan fossils from Hole 327A consist dominantly of comminuted debris of Aucellina shells (Figure 1 and Table 2), only a few of which are sufficiently well preserved for generic identification. For the most part, these scraps were identified on the basis of similarity in shell structure and ornamentation to larger specimens. Unidentified belemnite and snail fragments are also present.

\section{Site 330}

Megafossils obtained from Site 330 occur in Cores 1, $5,6,7,8,9$, and 10 (Figure 1 and Table 1) and consist of belemnites (including the genera Hibolithes and Belem- nopsis), bivalves (including the genera Inoceramus, Anomia, Aucellina, Plicatula, Malayomaorica, and a new genus herein named Jeletzkiella), together with fish scales, calcareous worm tubes, carbonaceous debris, and scraps of ammonite shells. The occurrence of these fossils is listed in Table 1; some of the bivalves are shown on Plates 1 and 2, but the remainder of the fauna has not been studied in detail, mainly because of poor preservation. Only the belemnites appear to merit additional work, and even these for the most part are fragmentary or comprise only small juvenile specimens, which are difficult to identify specifically.

\section{TAXONOMY}

\section{FAMILY BUCHIIDAE}

Aucellina sp. juv.

(Plate 1, Figures 1-4, 7, 8)

Description: Abundant comminuted shell debris is present in Hole $327 \mathrm{~A}$, and several fragments occur at Site 330 . Identification of this material as Aucellina sp. juv. is based on the character of the right valve, of which several extremely well preserved, but minute, specimens are available. The largest available right valve is shown on Plate 1; this specimen is about $8 \mathrm{~mm}$ long and $7 \mathrm{~mm}$ high and is too small for specific identification.

The characteristic features of Aucellina are well exhibited. The right valve is nearly flat; the umbo is small and situated near the center of the hinge line. The anterior ear is long with a narrow, curved byssal notch, both sides of which are lined by tubercles forming a well-developed ctenolium. Ornamentation consists of indistinct concentric growth lines crossed by narrow threadlike radial ribs. With increased growth; the radial ribs become progressively obsolete and the concentric growth lamellae become stronger and imbricated.

The nature of the hinge apparatus and interior of the anterior ear is well displayed on Plate 1, Figures 4, 7, 8; the anterior ear is slightly spoon-shaped, and the cardinal margin is smooth except for a minute, boss-like projection at the base of the anterior ear (see Plate 1, Figure 4).

In shape and ornamentation, the figured specimen is close to Aucellina aptiensis (d'Orbigny) as figured by Pompeckj (1901, pl. 16, fig. 1-4), the main difference being that Pompeckj's specimen has a slightly less projected anterior margin. 


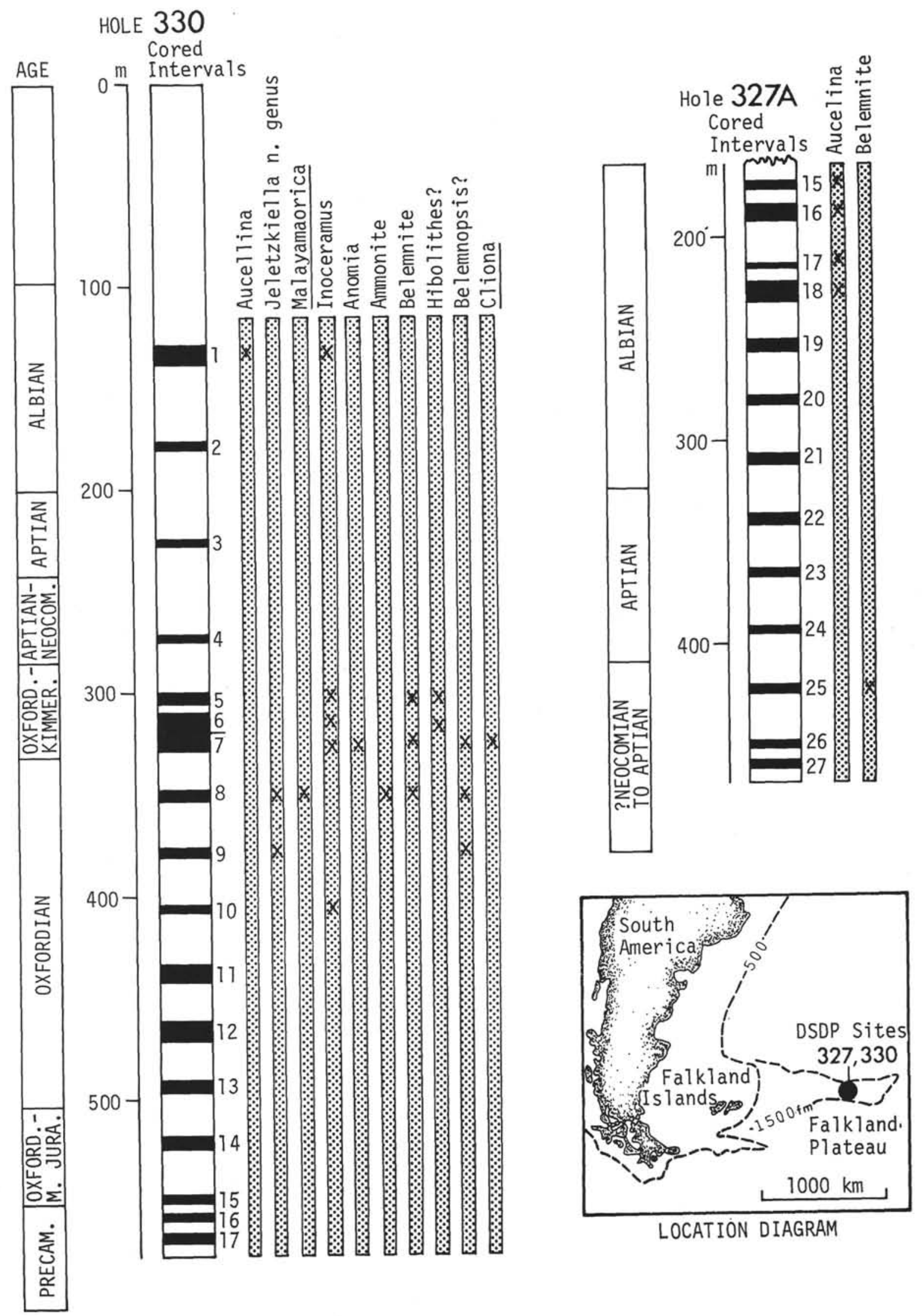

Figure 1. Distribution of megafossils at DSDP Hole 327A and Site 330, eastern Falkland Plateau. 
TABLE 1

Megafossils from Site 330

\begin{tabular}{|c|c|}
\hline $\begin{array}{l}\text { Sample } \\
\text { (Interval in } \mathrm{cm} \text { ) }\end{array}$ & Megafossil \\
\hline $1-1,3-5$ & Aucellina sp. indet. shell debris \\
\hline $1-1,5$ & Inoceramus shell debris \\
\hline $1-1,60$ & Inoceramus and Aucellina shell debris \\
\hline $1-4,113-114$ & Aucellina? sp. juv. shell debris \\
\hline $1-5,54-56$ & Aucellina? sp. juv. Inoceramus shell debris \\
\hline $5-2,65-79$ & Hibolithes? sp. indet \\
\hline $5-3,3-5$ & Inoceramus shell debris (Oxfordian nannos) \\
\hline $5-3,105$ & Belemnite fragments \\
\hline $5, \mathrm{CC}$ & Belemnite fragments - Hibolithes? \\
\hline $6-2,1$ & Hibolithes? sp. \\
\hline $6-2,17$ & Inoceramus scraps \\
\hline $6-2,28$ & Inoceramus scraps \\
\hline $6-2,50$ & Inoceramus scraps \\
\hline $6-3,63-64$ & Belemnite fragments \\
\hline $6-3,127-128$ & Hibolithes sp. indet. Inoceramus fragments \\
\hline $6-4,115-116$ & Inoceramus fragments \\
\hline $6-4,143-145$ & Inoceramus fragments \\
\hline $7-1,100-140$ & Belemnite scraps \\
\hline $7-1,114-116$ & Inoceramus scraps \\
\hline $7-3,30-31$ & Belemnite fragments \\
\hline $7-3,54-56$ & Inoceramus scraps \\
\hline $7-3,80-82$ & Inoceramus scraps \\
\hline $7-4,82-82$ & $\begin{array}{l}\text { Anomia sp. Belemnite fragment } \\
\text { Inoceramus fragment }\end{array}$ \\
\hline $7-4,115-117$ & $\begin{array}{l}\text { Cliona-bored shell fragment } \\
\text { (indicator of shallow water) }\end{array}$ \\
\hline $7-5,70-71$ & Belemnopsis? sp. indet. \\
\hline $8-2,118-120$ & $\begin{array}{l}\text { Belemnopsis? sp. Malayomaorica } \mathrm{cf} \text {. } \\
\text { M. malaymaorica (Krumbeck) } \\
\text { Age = early to mid Kimmeridgian } \\
\text { (Upper Jurassic) }\end{array}$ \\
\hline $8-3,120-124$ & Inoceramus (?) scraps, fish scales \\
\hline $8-3,125-126$ & $\begin{array}{l}\text { Malayamaorica } \mathrm{cf} \text {. } \text {. malaymaorica } \\
\text { Belemnite } \text { sp. indet }\end{array}$ \\
\hline $8-4,136-138$ & Malayamaorica cf. M. malayomaorica \\
\hline $8, \mathrm{CC}$ & $\begin{array}{l}\text { Jeletzkiella falklandensis new genus and species } \\
\text { Oxfordian? to early Kimmeridgian } \\
\text { ?Malayomaorica } \mathrm{cf} \text {. M. malayomaorica } \\
\text { Ammonite scrap, Belemnopsis sp. }\end{array}$ \\
\hline $9-1,102-103$ & Jeletzkiella falklandensis \\
\hline $9-1,113-115$ & Jeletzkiella falklandensis \\
\hline $9-2,23$ & Belemnopsis(?) sp. \\
\hline $9-2,122-123$ & Indet. shell scraps and fish scales \\
\hline $10-2,116$ & $\begin{array}{l}\text { Inoceramus scrap Worm tubes, Plicatula? sp. } \\
\text { carbonaceous debris }\end{array}$ \\
\hline
\end{tabular}

TABLE 2

Megafossils from Hole 327A

Core 15 , Section 2

Core 16, Sections 1-5

Core 17 , Section 2

Core 18 , Section $101,106 \mathrm{~cm}$

Core 21 , Section $3,102 \mathrm{~cm}$

Core 22, Section $2,134 \mathrm{~cm}$

Core 25

Age: Species of Aucellina are common in strata of Aptian to Albian age in Austral regions (see Speden, 1974, p. 977). They also are abundant in South America (Feruglio, 1937) and on the Antarctic Peninsula (Alexander Island; see Cox, 1953) in strata of Aptian age. Aucellina is not known to occur in Madagascar (Collignon, personal communication 1975; see also faunal lists in Besairie and Collignon, 1972), nor has it been reported elsewhere in southern Africa. As a specific determination is not warranted with the material in hand, only a general age assignment of Aptian to Albian is indicated.
Malayomaorica ef. M. malayomaorica (Krumbeck)

(Plate 2, Figures 3, 10, 11, 16, 17)

Description: Right valve is nearly flat, obliquely oval, higher than long. Anterior ear is short and blunt, with a wide byssal notch. The anterior edge of this ear is twisted away from the plane of the valves and projects outward at a nearly right angle to the plane of the valves (see Plate 2, Figure 17). The ligamental area of the right valve is broad and sculptured by a distinct sinus that projects posteriorly from just below the umbo. This sinus lies between the anterior ear and the anterior side of a slight swelling that articulates in a corresponding shallow groove of the left valve. Ornamentation consists of irregular concentric growth lines.

The left valve is more inflated and oblique. The ligamental area is broad, striated, and marked by a distinct transverse sinus or groove that begins just below the umbo and runs obliquely in a posterior direction. The anterior margin of the shell is abruptly truncated and bent just below the umbo to form a conspicuous gape. Ornamentation consists of irregular subimbricate concentric growth lamellae and, on several specimens, faint radial striae.

The specimens of Malayomaorica from Site 330 exhibit some differences from typical Indonesian or New Zealand specimens of $M$. malayomaorica, as figured by Jeletzky (1963), and others. The ligamental area of the left valve in the former is not so broad; the radial ornamentation is not so well developed; the anterior ear of the right valve is smaller; and the anterior margin of the left valve is more abruptly truncated. Some of these differences may be related to the very small size of all the specimens available from Site 330, none of which shows adult characteristics.

Material: One well-preserved fragment of a left valve and a small right valve are illustrated on Plate 2. Many other very small fragments are present. Distribution of these is shown in Table 1.

Age: Malayomaorica malayomaorica is well known in Upper Jurassic strata of New Zealand, Indonesia, New Guinea, and New Caledonia. At Kawhia Harbour, New Zealand, this species occurs in strata of early to middle Kimmeridgian age (Fleming, 1960, table 1, p. 267). A Kimmeridgian age is also assigned to the New Guinea occurrence (Skwarko, 1967) and also to the New Caledonian subspecies M. malayomaorica novacaledonica Freneix, Grant-Mackie, and Lozes (1974). M. malayomaorica is widespread in Indonesia, occurring in Timor, Misol, Ceram, and Buru (Freneix et al., 1974, p. 461). These Indonesian occurrences are thought by Jeletzky $(1963$, p. 152) to also be of early to middle Kimmeridgian age.

\section{Jeletzkiella n. gen.}

Type species: Jeletzkiella falklandensis Jones and Plafker, n. sp. Description: Buchia-like bivalved shell, obliquely elongate; right valve nearly flat with inconspicuous umbo located near the middle of the dorsal side, left valve moderately inflated with umbo that projects over the right valve; ornamentation consists of irregular growth striae. The character of the hinge and the anterior ear of the right valve clearly separates this new genus from other related genera of the family Buchiidae. The anterior ear is a large, blade-like structure that projects obliquely forward across the plane of the valves and into a corresponding sulcus, or gape, in the anteriodorsal margin of the left valve.

\section{Jeletzkiella falklandensis Jones and Plafker, n. sp.} (Plate 2, Figures 1-7, 9, 12-15)

Holotype: USNM 240489A-E.

Description: Right valve obliquely oval with inconspicuous umbo located near the middle of the dorsal margin. Exterior portion of the anterior ear is small, triangular, and separated from the main part of the valve by a very narrow byssal notch. The entire ear is a large, bladelike structure, the dorsal side of which forms a shallow, nearly flat to gently concave surface, and the ventral side of which is elongated obliquely forward and projects outward toward the left valve (Plate 2, Figures 9, 14,15). A clearly defined ligamental area is not present. The left valve is obliquely oval, moderately inflated, and nearly smooth. The ligamental area is very narrow (Plate 1, Figures 5 , 6) with a very shallow, oblique sulcus present under the umbo. The anteriodorsal margin is deeply excavated.

Discussion: The differences between the structure of the anterior ear of J. falklandensis and other related forms are clearly shown on Plates 1 and 2. Malayomaorica differs in having a wide byssal notch, a 
broad ligamental area, and a smaller anterior ear that is folded outward nearly at right angles to the plane of the valves. The left valve has a much broader ligamental area with a more distinct transverse groove.

Early forms of Buchia, such as Buchia concentrica and B. mosquensis (see Plate 1, Figure 13), have a small spoon-shaped ear that lies essentially in the plane of the valves, as shown by Jeletzky (1963, p. 157). In younger species of Buchia, Jeletzky has shown that this ear becomes larger and stouter and bends toward the left valve (see Plate 1, Figures 9-11 for a specimen of $B$. pacifica from California that clearly shows the bent nature of the anterior ear in a Valanginian species).

Another Indopacific species, Buchia plicata (Zittel), which is well known from Late Jurassic (early Tithonian, according to Fleming, 1958, p. 383; see also Fleming, 1959) deposits of New Zealand, superficially resembles the right valve of Jeletzkiella falklandensis (compare Plate 1, Figures 5, 6, 14 and Plate 2, Figure 1), but this species differs in having a very different anterior ear and a broad ligamental area.

The right valves of $J$. falklandensis and Malayomaorica malayomaorica are grossly similar in juvenile specimens. The ligamental area of the latter, however, is much broader with a deeper and more clearly defined transverse sulcus.

Material: Five recognizable right valves and three left valves, plus numerous unidentifiable scraps.

Stratigraphic position and age: Jeletzkiella falklandensis occurs in Sample 330-8, CC and in Section 1 of Core 9 (Table 1), which is stratigraphically below the interval characterized by Malayomaorica cf. M. malayomaorica of probable early to middle Kimmeridgian age. An early Kimmeridgian age also seems appropriate for the upper range of Jeletzkiella, but the age of the underlying specimens from Core 9 might be as old as late Oxfordian.

\section{POSTULATED DEPTH OF DEPOSITION}

All the molluscan fossils obtained from Hole 327A and Site 330 are indicative of relatively shallow water conditions. Probable depths were no greater than 200 meters and may have been considerably less. The several species of the family Buchiidae (Aucellina, Malayomaorica, and Jeletzkiella) were all byssate attached forms and lived exclusively in neritic waters. Belemnites likewise are good indicators of neritic depths.

\section{REGIONAL SIGNIFICANCE OF THE MOLLUSCAN FOSSILS}

As shown by Figure 2, the known occurrences of Malayomaorica malayomaorica are restricted to the Austral regions of reassembled Gondwanaland, and

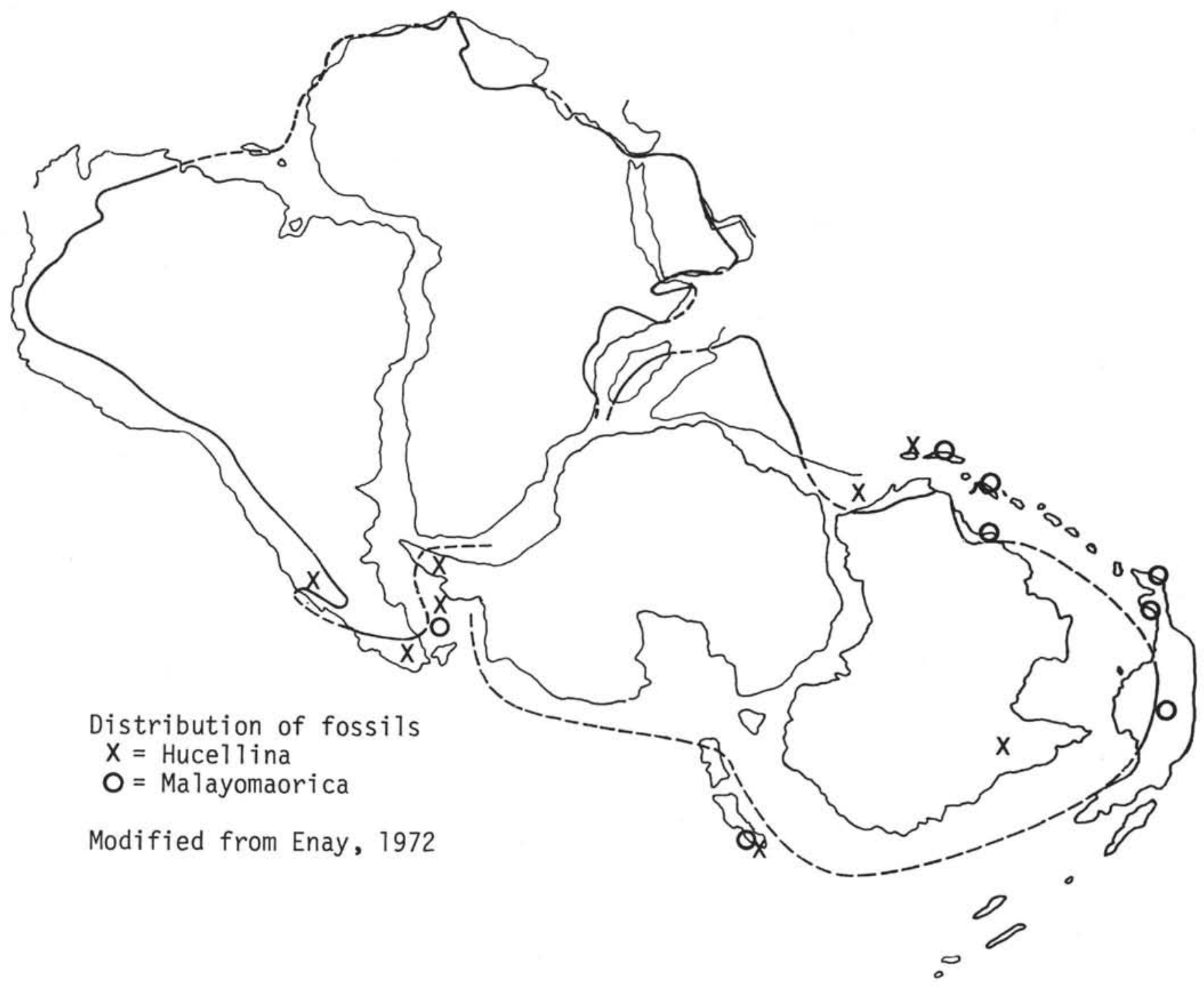

Figure 2. Distribution of Malayomaorica and Aucellina. 
they extend around the eastern side of Australia as far as Indonesia. Of particular significance is the absence of Malayomaorica from Kimmeridgian strata of Madagascar (see Enay, 1972; Besairie and Collignon, 1972) or from Upper Jurassic strata occurring along the southern and southeastern coast of South Africa (see Dingle, 1973b, p. 99). Dingle (1973a, p. 208) suggests that during Late Jurassic time a marine connection existed between the southern tip of Africa and Madagascar. This connection is substantiated by the presence of a probable middle Kimmeridgian ammonite from the Brenton beds of the Knysna outlier, located about $400 \mathrm{~km}$ due east of Cape Town (Klinger, et al., 1972). Similar Tethyan forms occur in Madagascar and elsewhere in northeastern Africa (Klinger et al., 1972, p. 658) and ostracodes from the Brenton beds also show strong affinities to Upper Jurassic faunas of Madagascar (Klinger et al., 1972).

Aucellina in Austral regions has a distribution similar to that of Malayomaorica (see Figure 2), although it is also widely known throughout Boreal regions, where it occurs in California, Alaska, northern Canada, and northern Europe. Its absence from deposits of Aptian to Albian age in southern Africa and Madagascar appears to be well documented.

Reconstruction of the predrift position of the Falkland Plateau as shown on Figure 3 juxtaposes rocks of comparable age but with differing faunal affinities. This reconstruction was suggested by Barker et al. (1974).

The implication of these faunal differences is that some form of barrier must have effectively separated the dominantly Tethyan faunas of Africa and Madagascar from the Austral faunas of the eastern

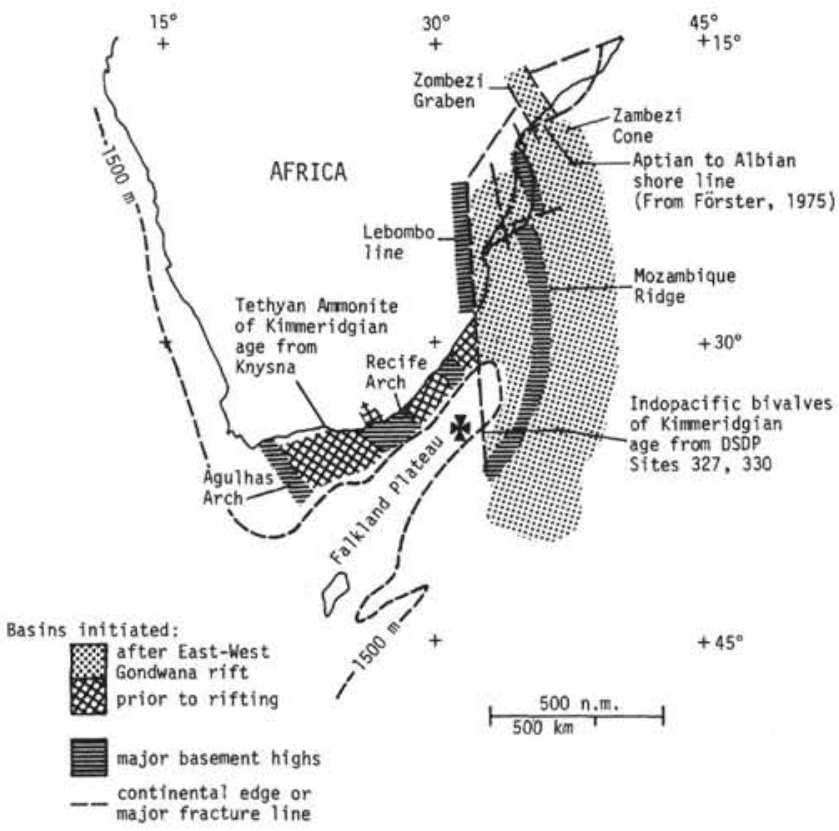

Figure 3. Postulated relationship of Falkland Plateau and DSDP Hole 327 and Site 330 to major sediment basins, basement highs, and fracture lines in existence prior to breakup of West Gondwana (Late) Jurassic time.
Falkland Plateau. This poses some limits to the predrift placement of the eastern Falkland Plateau in relation to the southern African coast. It also suggests that the plateau from at least Late Jurassic through much of Cretaceous time (see foraminiferal data of Sliter, this volume) was directly connected to the Antarctic Peninsula and the southern tip of South America and was not directly connected to the southeast coast of Africa. Any postulated scheme of reassembly of predrift Gondwanaland must permit ready access of Austral marine waters and faunas into the site of the eastern Falkland Plateau and must effectively bar entrance to the Tethyan faunas that seemingly lived in proximity. This could be achieved in several ways:

1) A long, narrow elevated landmass may have lain between two separate seaways, the western one characterized by Tethyan faunas and the eastern by Austral faunas.

2) Unidentified paleoecological conditions, such as local upwelling, may have permitted cool Austral faunas to exist as faunal outliers in a region generally dominated by warmer water forms.

3) The reconstructed position of the Falkland Plateau as shown in Figure 3 may be incorrect. Rather than extending northeastward along the southeast coast of Africa, the eastern part of the plateau may have originally lain much farther to the south. Its present position could then be the result of post-Cretaceous movements related to the formation of the Scotia Arc. A possible reconstruction showing this alternative is given in Figure 4. According to this interpretation, the eastern Falkland Plateau would be a displaced continental fragment that is not structurally continuous with the western part of the plateau on which the Falkland Islands are situated.

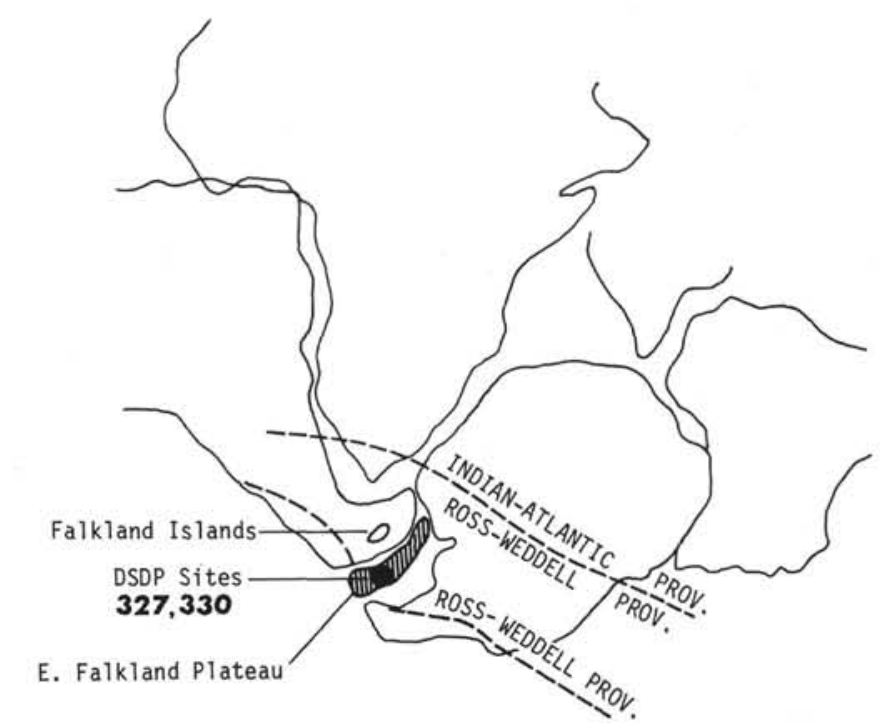

Figure 4. Possible position of the eastern Falkland Plateau ("Ewing miniplate") prior to breakup of Gondwanaland. Gondwanaland model modified from Veevers et al (1971) and major tectonic province boundaries of Antarctica and adjacent plates after Ford (1972). 
This hypothesis appears to us to be the most likely explanation to account for the distribution of faunas, particularly when the foraminiferal data are also considered (see Sliter, this volume). Further speculations concerning the predrift position of the Falkland Plateau are given in the Cruise Synthesis (see Dalziel et al., this volume).

\section{ACKNOWLEDGMENTS}

We wish to acknowledge the support and assistance of the entire crew of DSDP Leg 36, particularly the Co-chief Scientists Ian Dalziel and Peter Barker, for making the material described herein available for study. Dr. George Jeletzky of the Geological Survey of Canada offered valuable advice on the identification and classification of the bivalve specimens, and we have acknowledged our debt to him by naming a new genus of the Family Buchiidae Jeletzkiella. We also thank Dr. Ian Speden of the Geological Survey of New Zealand for loaning us several specimens of Buchia plicatula from New Zealand.

Robert Oscarson of the U.S. Geological Survey took the SEM photographs and Kenji Sakamoto, also of the Survey, took the regular photographs in reflected light.

\section{REFERENCES}

Barker, P.F., et al., 1974. Southwestern Atlantic: Geotimes v. 19 , p. 16-18.

Besairie, and Collignon, M., 1972. Géologie de Madagascar. 1. Les terrains sédimentaires: Annales Géol. Madagascar, Fasc. 35, 463 p.

Cox, L.R., 1953. Lower Cretaceous Gastropoda, Lamellibranchia, and Annelida from Alexander I Land (Falkland Islands Dependencies): Falkland Islands Dependencies Surv., Sci. Rept., no. 4, 14 p.

Dingle, R.V., 1973a. Mesozoic palaeogeography of the southern cape, South Africa: Paleogeogr., Paleoclimatol., Palaeoecol., v. 13, p. 203-213.

$1973 \mathrm{~b}$. Regional distribution and thickness of postPaleozoic sediments on the continental margin of southern Africa: Geol. Mag., v. 110, p. 97-208.

Dingle, R.V. and Scrutton, R.A., 1974. Continental breakup and the development of post-Paleozoic sedimentary basins around southern Africa: Geol. Soc. Am. Bull., v. 85, p. $1467-1474$.
Enay, R., 1972. Paleobiogéographie des ammonites du Jurassique términal (Thithonique/Volgien/Portlandien s.l.) et mobilité continental: Geobios, no. 5, fasc. 4, p. 355-407.

Feruglio, E., 1937. Palaentolographica Patagonica: Padova Univ. Ist. Geol. Mem., v. 11, 192 p.

Fleming, C.A., 1958. Upper Jurassic fossils and hydrocarbon traces from the Cheviot Hills, North Canterbury: New Zealand J. Geol. Geophys., v. 1, p. 375-394. 1959. Buchia plicata (Zittel) and its allies, with a description of a new species, Buchia hochstetteri: New Zealand J. Geol. Geophys., v. 2, p. 889-904. 1960. The Upper Jurassic sequence at Kawhia, New Zealand, with reference to the ages of some Tethyan guide fossils: Internat. Geol. Cong., 21st, pt. 21, p. 264269.

Förster, R., 1975. The geological history of the sedimentary basin of southern Mozambique, and some aspects of the origin of the Mozambique channel: Palaeogeogr., Palaeoclimatol., Palaeoecol., v. 17, p. 267-287.

Ford, A.B., 1972. Fit of Gondwana continents-Drift reconstruction from the Antarctic continental viewpoint: Internat. Geol. Congr., v. 24, p. 113-121.

Freneix, S., Grant-Mackie, J.A., and Lozes, J., 1974. Présence de Malayomaorica (Bivalvia) dans le Jurassique supérieur de la Nouvelle-Calédonie: Soc. Géol. France Bull., 7 th ser., v. 16 , p. $456-464$.

Jeletzky, J.A., 1963. Malayomaorica gen. nov. (Family Aviculopectinidae) from the Indopacific Upper Jurassic; with comments on related forms: Palaeontology, v. 6, p. $148-160$.

Klinger, H.C., Kennedy, W.J., and Dingle, R.V., 1972. A Jurassic ammonite from South Africa: Neues Jahrb. Geol., Paläont. Mh., v. 11, p. 653-659.

Pompeckj. J.F., 1901. Ueber Aucellen und Aucellen-áhnliche Formen: Neues Jahrb. Min., Geol., Palaeont., 14 Beil. Bd., p. 319-368.

Skwarko, S.K., 1967. Mesozoic Mollusca from Australia and New Guinea: Australian Bur. Min. Res., Geol., Geophys., Bull. 75, 100 p.

Speden, I.G., 1974. Cretaceous Bivalvia from cores, Leg 27. In Heirtzler, J., Veevers, J.J., et al., Initial Reports of the Deep Sea Drilling Project, Volume 27: Washington (U.S. Government Printing Office), p. 977-978.

Veevers, J.J., Jones, J.G., and Talent, J.A., 1971. IndoAustralian stratigraphy and the configuration and dispersal of Gondwanaland: Nature, v. 229, p. 383-388. 



\section{PLATE 1}

Figures natural size except as indicated.

Figures 1-4, 7, 8 Aucellina sp. juv. Right valve, USNM 240486 Sample 227A-18, CC.

1-3. Exterior, interior, and dorsal views, $\times 2$.

4. Interior of anterior ear, $\times 50$. SEM photo.

7. Umbonal region, showing anterior ear and ligamental area, $\times 22$. SEM photo.

8. Ctenolium, $\times 54$. SEM photo.

Figures 9-11 Buchia pacifica (Jeletzky). Right valve, USNM 240487, from USGS Mesozoic loc. M3086, northern California. This specimen illustrates the bent character of the anterior ear of Lower Cretaceous species of Buchia.

Figures 5,6, Buchia plicata (Zittel).

12,145 . Right valve and umbo of left valve; New Zealand Geological Survey No. 9706.

6. Right valve, plaster cast of unnumbered specimen from the New Zealand Geological Survey. Note resemblance of anterior ear and shape of right valve to that of Jeletzkiella falklandensis figured on Plate 2.

12. Interior of right valve, rubber cast of New Zealand Geological Survey No. 5255. Shows internal character of anterior ear. Compare with that of Jeletzkiella falklandensis, Plate 2.

14. Right valve, rubber cast of New Zealand Geological Survey No. 3851. Note broad, striated ligamented area.

Figure 13 Buchia mosquensis (von Buch). Internal view of right valve, showing flat, spoonlike character of anterior ear. Rubber cast of USNM 240488 from USGS Mesozoic loc. M5226, Alaska Peninsula. 
PLATE 1

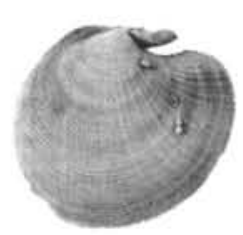

1

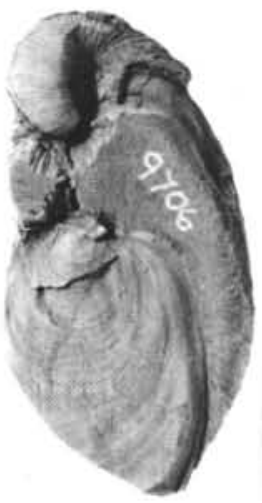

5

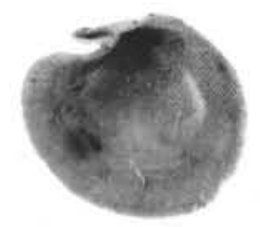

2

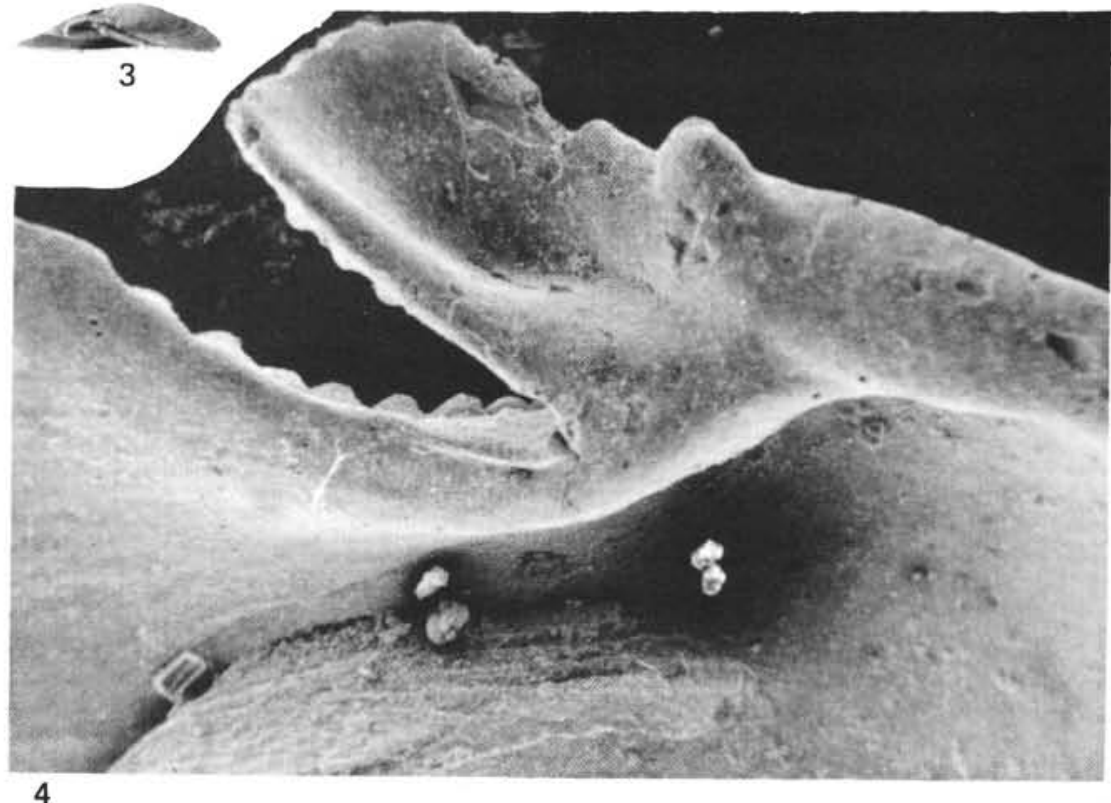

6
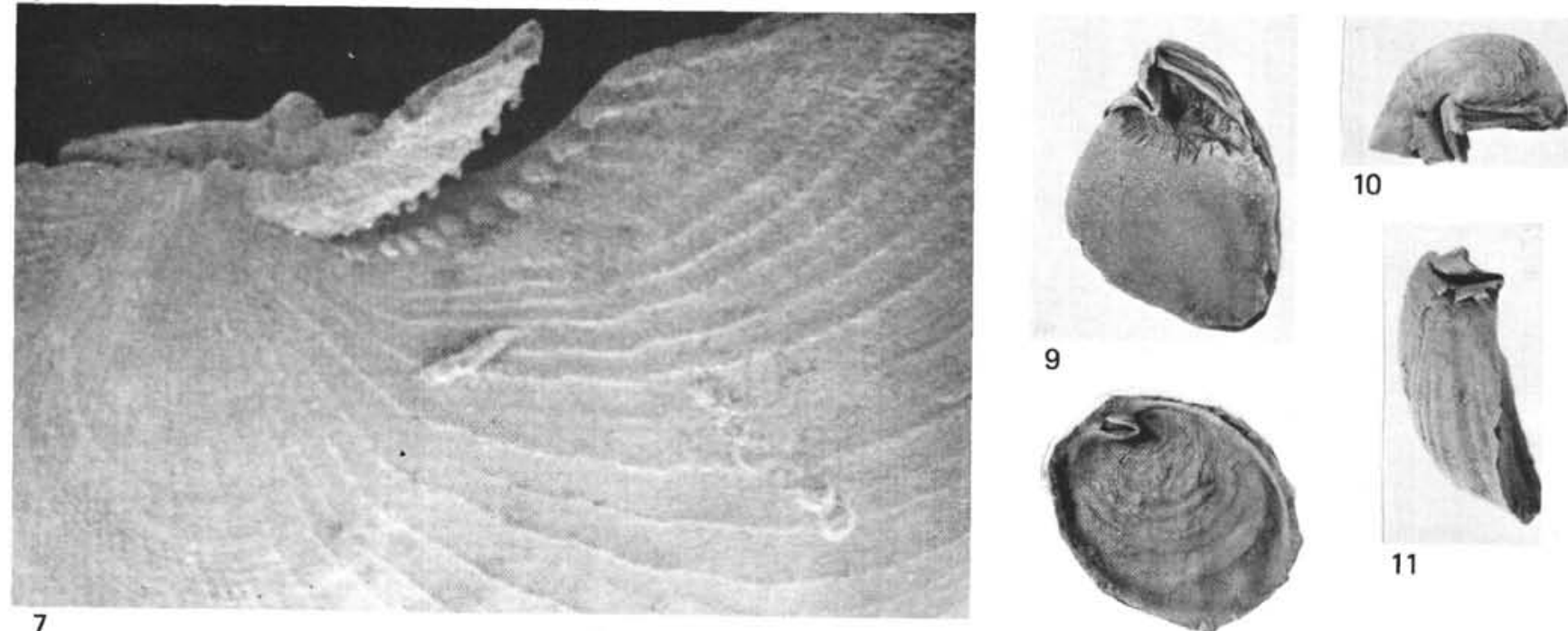

9
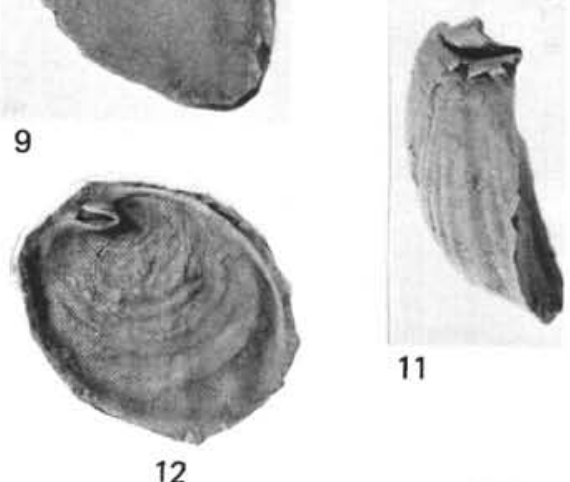

11
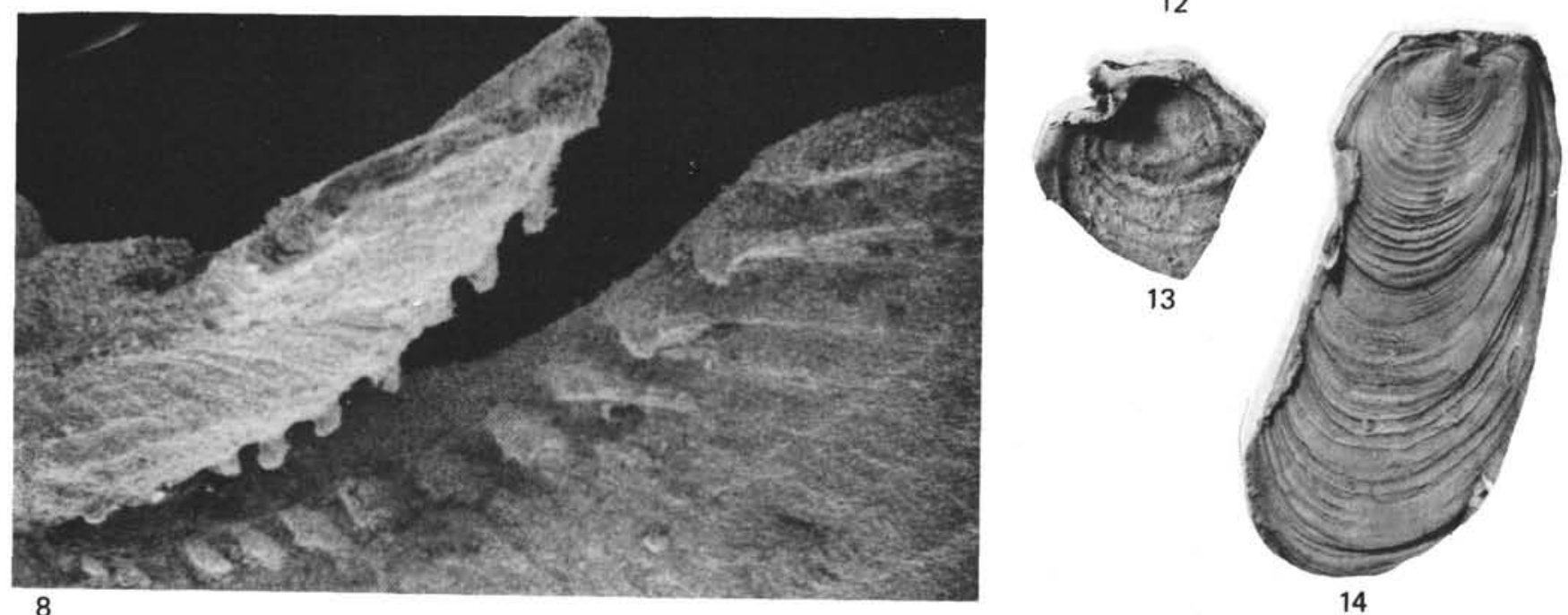


\section{PLATE 2}

Size of figures as indicated.

Figures 1-7,9, Jeletzkiella falklandensis, n. gen., n. sp. All $12-15$ specimens from Sample 330-8, CC.

$1,2,3,9,12,14,15$. Holotype, USNM 240489A. 1. Exterior of right valve, note small triangular anterior ear. $\times 2$.

2, 9. Dorsal views; note bladelike anterior ear projecting forward away from the plane of the valves. $\times 2, \times 4$.

3,12 . Interior views, $\times 2, \times 4$.

14. Ventral view of anterior ear, looking through byssal notch. SEM photo, $\times 30$.

15. Lateral view of anterior ear, showing bladelike character of anterior ear, with a nearly flat shelf on the dorsal side. SEM photo, $\times 30$.

4. Fragments of right valve, USNM $240489 \mathrm{~B}, \times 2$.

5. Left valve with dislocated right valve. USNM 240489C. $\times 2$.

6, 7. Interior and exterior of left valve, USNM 240489D. Note very narrow ligamental area (compare with Figures 10,11).

13. Split core with right valve and several fragments, left valves, USNM 240489E. Tip of anterior ear is broken. $\times 1$.

Figures 8, 10, Malayomaorica cf. $M$. malayomaorica (Krum11, 16-18 beck).

$8,16,17$. Dorsal, exterior, and interior views of right valve, USNM 240490A from Sample 330-8$2,118 \mathrm{~cm}$. Note wide byssal notch, wide ligamental area, and difference in shape of anterior ear from Jeletzkiella falklandensis. $\times 2$.

10, 11. Right valve, USNM 240490B, from Sample $330-8-4,138 \mathrm{~cm}$. Note wide, horizontally striate ligamental area with shallow oblique groove beneath umbo. $\times 2, \times 4$.

18. Fragments of $M$. cf. $M$. malayomaorica(?), USNM 240491, from Sample 330-8-2, $138 \mathrm{~cm}$ (?), showing subimbricate concentric growth lines. $\times 2$. 
PLATE 2

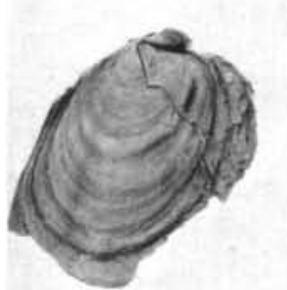

1

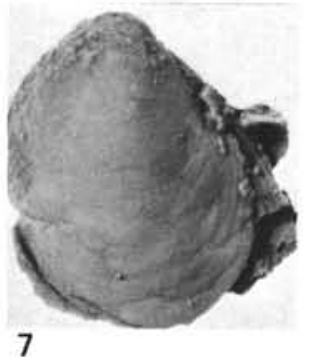

7
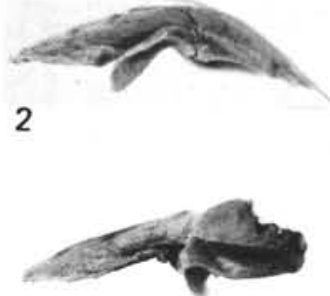

8

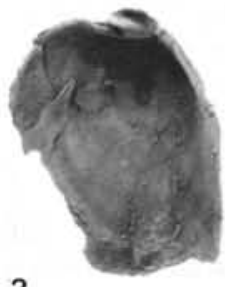

3
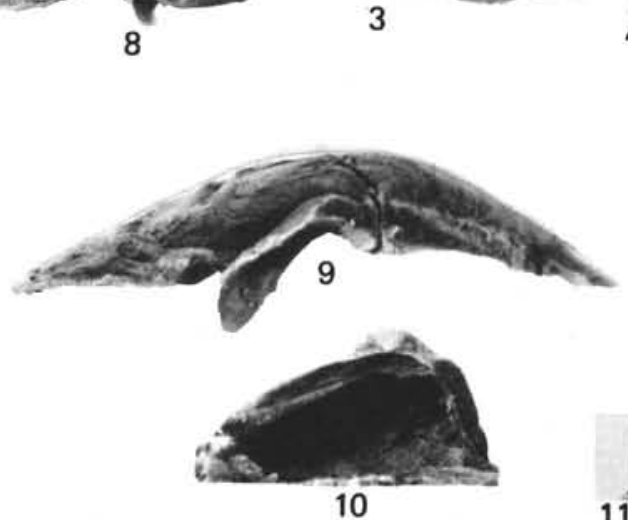
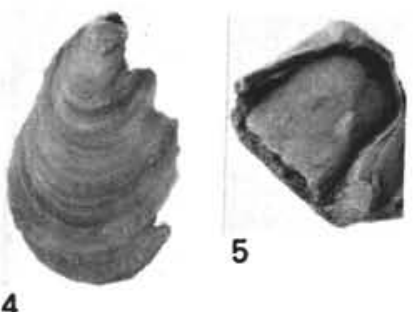

5
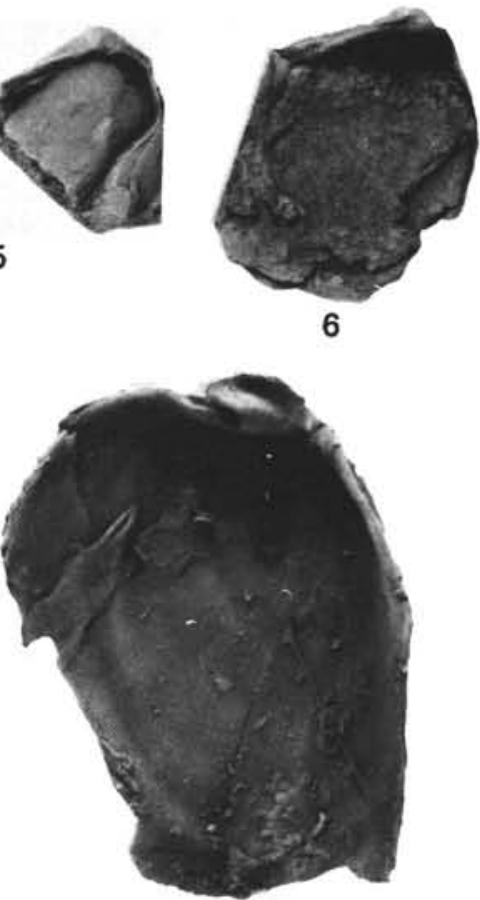

12

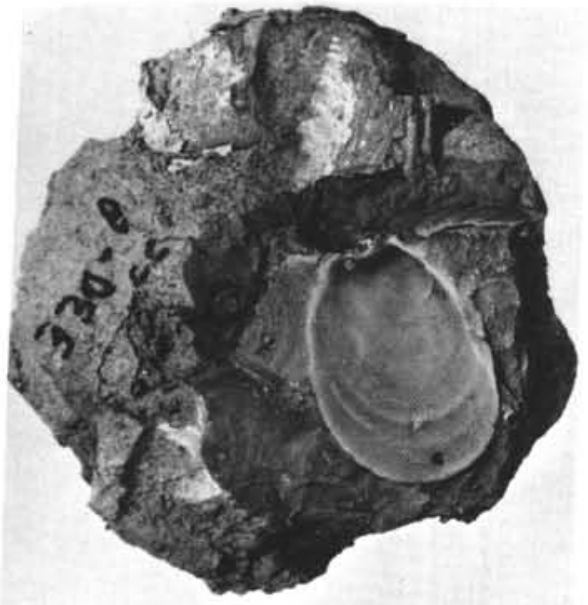

13
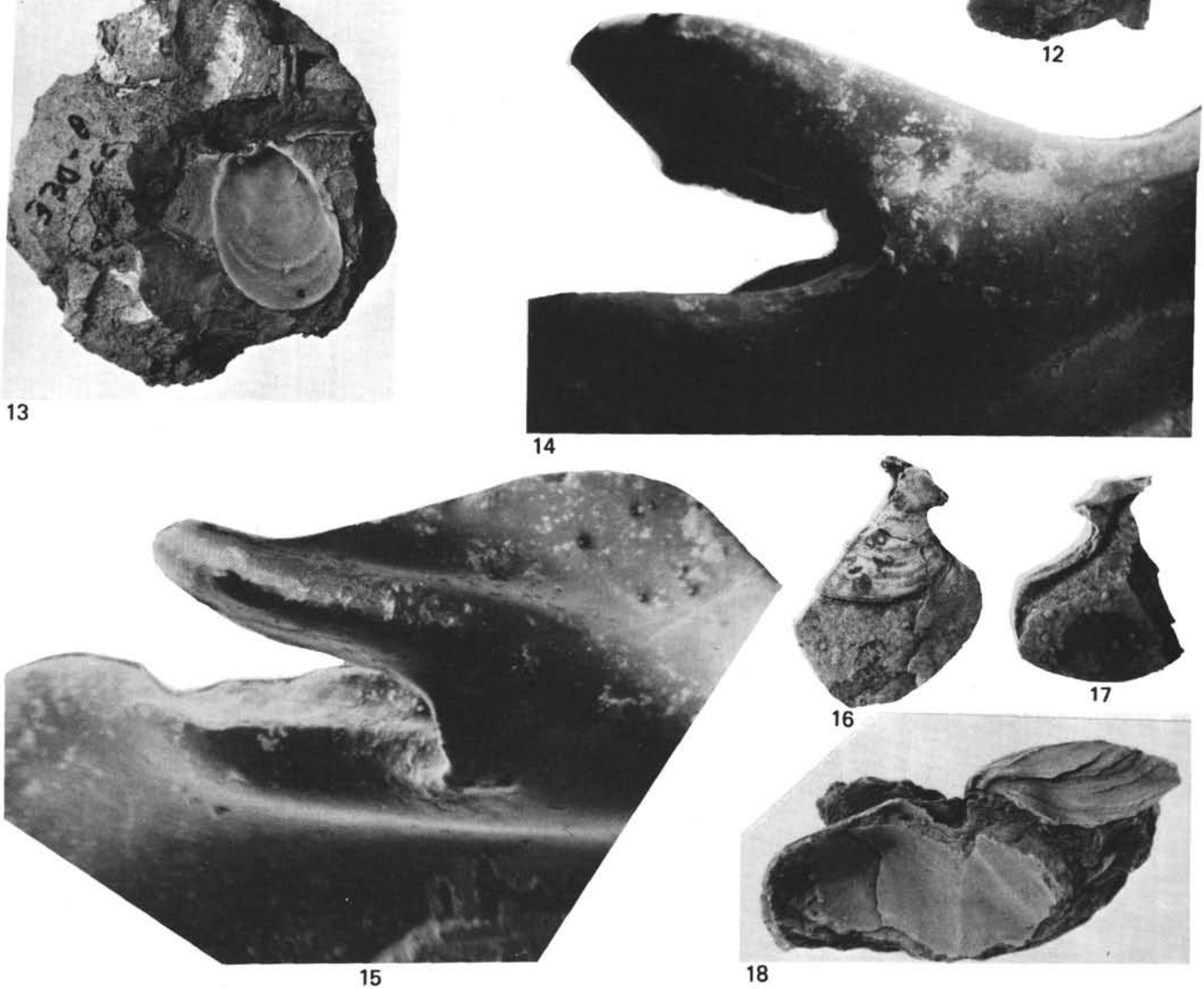